Jurnal Psikologi Teori dan Terapan

2016, Vol.7, No. 1, 43-49, ISSN: 2087-1708

\title{
Kepercayaan Diri dan Kemandirian Belajar Pada Siswa SMA Negeri "X"
}

\author{
Iffa Dian Pratiwi, dan Hermien Laksmiwati \\ Program Studi Psikologi Universitas Negeri Surabaya
}

\begin{abstract}
This research was aimed to examine the correlation between self confidence and learning independency among senior high school students. This research was a quantitative study which involved all student of class XI social science major (ilmu pengetahuan sosial/IPS) in SMA Negeri 1 Porong with the total number of 88 students. The instrument used to collect data were self confidence and independent learning scales. Data were analyzed using Pearson's product moment. The result shows that the coefficient correlation is $0,683(r=0,683)$ in the significant level of 0,000 $(p=0,000)$. The result means that there is correlation between self confidence and learning independency in which the relation between both variables is unidirectional. So, the higher the self confidence student have, the higher their learning independency would be and vice versa.
\end{abstract}

Keywords: Self-confidence, independent learning, student.

\begin{abstract}
Abstrak: Tujuan penelitian ini adalah untuk menguji hubungan antara kepercayaan diri dengan kemandirian belajar pada siswa XI IPS SMA Negeri 1 Porong. Penelitian ini merupakan penelitian kuantitatif dengan jumlah sampel sebanyak 88 siswa di SMA Negeri 1 sehingga disebut penelitian populasi, karena jumlah subjek penelitian dibawah 100. Instrumen penelitian yang digunakan adalah skala kepercayaan diri dan skala kemandirian belajar. Analisis data menggunakan product moment. Hasil analisis data menunjukkan nilai koefisien korelasi sebesar $0,683 \quad(\mathrm{r}=0,683)$ dengan taraf signifikan $0,000(\mathrm{p}=0,000)$ artinya terdapat hubungan antara variabel kepercayaan diri dengan kemandirian belajar dimana hubungan antar variabel adalah searah. Oleh karena itu, semakin tinggi kepercayaan diri yang dimiliki siswa, maka semakin tinggi pula kemandirian belajarnya, dan sebaliknya.
\end{abstract}

Kata Kunci : Kepercayaan diri, kemandirian belajar, siswa

Hakikatnya setiap manusia memerlukan pendidikan dalam kehidupannya. Pendidikan mempunyai peran penting dalam kelangsungan hidup dimasa yang akan datang. Peran penting tersebut untuk mengembangkan potensi dalam dirinya. Menurut UU Nomor 20 tahun 2003 pada pasal 3 tujuan pendidikan yaitu mewujudkan suasana belajar dan proses pembelajaran agar peserta didik secara aktif mengembangkan potensi dalam dirinya untuk menjadi manusia yang beriman dan bertakwa kepada Tuhan Yang Maha Esa, berakhlak mulia, sehat, berilmu, cakap, kreatif, mandiri dan menjadi warga negara yang demokratis serta bertanggungjawab. Salah satu komponen yang dibutuhkan dalam pelaksanaan sistem pendidikan di Indonesia yaitu kurikulum. Kurikulum di Indonesia umumnya selalu mengalami pengembangan, hal ini dilakukan dengan mengacu standar nasional pendidikan

Korespondensi tentang artikel ini dapat dialamatkan kepada Iffa Dian Pratiwi melalui email: iffadp@gmail.com 
untuk mewujudkan tujuan pendidikan. Kurikulum yang digunakan di Indonesia saat ini yaitu kurikulum 2013. Kurikulum 2013 menekankan peran siswa yang aktif dalam pembelajaran dan peran guru hanyalah sebagai fasilitator, atau sering disebut dengan learned centered. Perubahan kurikulum pendidikan di Indonesia menjadi kurikulum 2013 disesuaikan dengan tujuan pendidikan yaitu untuk mewujudkan suasana belajar dan proses pembelajaran agar peserta didik secara aktif mengembangkan potensi dalam dirinya.

Implementasi kurikulum 2013 diterapkan pada semua jenjang pendidikan, tak terkecuali pada jenjang pendidikan sekolah menengah atas (SMA). Salah satu karakteristik peserta didik sekolah menengah atas (SMA) yaitu peserta didik memasuki usia 15-18 tahun. Menurut Santrock (2003) rentang usia 15-18 tahun tergolong pada masa remaja. Pada masa remaja banyak sekali tugas-tugas perkembangan yang harus diselesaikan, salah satunya yaitu kemandirian.

Menurut Knowles (dalam Nurhayati, 2011) kemandirian belajar (self directed learning) merupakan suatu proses dimana individu bertanggung jawab penuh serta berinisiatif dalam mendiagnosis kebutuhan belajar, merumuskan tujuan belajar, mengidentifikasi sumber belajar, memilih dan mengimplementasikan strategi belajar dan mengevaluasi hasil belajar. Salah satu tugas seorang siswa yaitu mampu mengambil tanggungjawab belajar mereka sendiri, agar tidak menggantungkan diri kepada orang lain dan mampu mengelola dirinya kapan waktu yang tepat untuk meminta bantuan kepada orang lain dan kapan tidak membutuhkan bantuan dari orang lain dalam belajar

Kemandirian belajar diperlukan dalam sistem pendidikan, agar tercapai tujuan pembelajaran yang menekankan siswa aktif dalam mengembangkan potensinya. Hal ini dikarenakan siswa dapat mengontrol sendiri berbagai cara belajar yang perlu ditempuh untuk mencapai hasil prestasi belajar sesuai dengan keinginannya. Pencapaian prestasi belajar di sekolah yang optimal dalam proses belajar siswa dapat didapatkan dengan adanya kemandirian belajar siswa.

Pada konteks proses belajar, terlihat adanya fenomena peserta didik yang kurang mandiri dalam belajar, yang dapat menimbulkan gangguan mental setelah memasuki pendidikan lanjutan, kebiasaan belajar yang kurang baik seperti tidak betah belajar lama atau belajar menjelang ujian, membolos, menyontek, dan mencari bocoran soal-soal ujian. Fenomenafenomena di atas, menuntut dunia pendidikan untuk mengembangkan kemandirian belajar pada peserta didik (Desmita, 2011). Kemandirian belajar memang sangat diperlukan dalam meningkatkan prestasi siswa, terlebih lagi dengan diberlakukannya kurikulum 2013 yang menuntut siswa untuk lebih berperan aktif.

Kemandirian belajar dapat dilaksanakan oleh seseorang apabila seseorang tersebut memiliki kepercayaan diri. Menurut Heaters (dalam Nurhayati, 2011) kemandirian belajar seseorang ditunjukkan dengan adanya kepercayaan diri akan kemampuannya dalam menyelesaikan berbagai macam permasalahan yang ada selama kegiatan belajar berlangsung, tanpa bantuan dari orang lain dan tidak ingin dikontrol pengambilan keputusannya untuk menyelesaikan permasalahan tersebut. Sama halnya dengan pernyataan (Desmita, 2011) kemandirian belajar siswa muncul ketika siswa menemukan diri pada posisi kepercayaan diri yang meningkat.

Menurut Hakim (2002) kepercayaan diri merupakan suatu keyakinan seseorang terhadap segala sesuatu yang menjadi aspek kelebihan yang dimiliki dan keyakinan tersebut membuatnya merasa mampu untuk mencapai berbagai tujuan hidup dan dapat menyesuaikan diri dengan lingkungannya. Individu yang berada pada 
tingkat kepercayaan diri yang tinggi, mampu menerapkan pikiran positif dalam dirinya untuk dapat mengelola semua kebutuhan hidupnya, termasuk kebutuhan belajarnya. Siswa yang memiliki kepercayaan diri tinggi, akan mampu mengelola belajarnya dengan baik, tanpa bergantung kepada orang lain.

Menurut Hiemstra (Nurhayati, 2011) ciri-ciri pebelajar yang memiliki kemandirian belajar yaitu (1) pelajar mempunyai tanggungjawab dalam pengambilan keputusan yang berhubungan dengan usaha belajar, (2) Memiliki keyakinan akan kemampuan yang dimilikinya (3) Tidak mudah terpengaruh oleh orang lain mengenai proses belajarnya, (4) Apabila menjumpai masalah, berusaha untuk dipecahkan sendiri dan mampu mengatur diri kapan harus meminta bantuan orang lain, serta tidak lari dari masalah, (5) Dapat memanfaatkan waktu dengan sebaik mungkin untuk belajar. Berdasarkan uraian ciri-ciri mengenai individu yang memiliki kemandirian belajar terdapat salah satu ciri yaitu memiliki keyakinan akan kemampuan yang dimilikinya. Keyakinan merupakan salah satu aspek kepercayaan diri. Individu yang yakin dengan kemampuannya adalah individu yang berpikiran positif terhadap kemampuannya untuk menyelesaikan berbagai persoalan dalam belajar. Oleh karena itu, kepercayaan diri mempunyai kontribusi dalam menumbuhkan kemandirian belajar siswa.

SMA Negeri 1 Porong, merupakan salah satu sekolah yang berstatus negeri. Pada sekolah ini terdapat dua jurusan program sekolah yaitu IPA dan IPS. Pada siswa kelas XI IPS didapatkan fenomena mengenai kemandirian belajar dan kepercayaan diri. 3 siswa mengatakan bahwa dirinya masih menunggu perintah dari orang tua untuk belajar, 2 siswa mengatakan bahwa mereka menggunakan waktu luangnya dirumah untuk bermain dibandingkan dengan belajar, 1 siswa mengatakan bahwa dirinya belajar atas kemauannya sendiri dan berusaha semaksimal mungkin dalam menyelesaikan tugasnya, 1 siswa lainnya mengatakan bahwa dirinya belajar secara fleksibel atau tidak menentu, tergantung keinginannya untuk belajar tinggi atau rendah.

Fenomena lainnya ketika presentasi dikelas siswa cenderung pasif, tidak yakin dengan kemampuannya ketika mengerjakan tugas, selain itu siswa juga tidak yakin dalam pemilihan jurusan sehingga menggantungkan diri kepada orang lain dalam pengambilan keputusan pemilihan jurusan, perbuatan menyontek juga masih dilakukan dengan bergantung pada salah satu temannya yang pintar mereka akan menyontek pada temannya tersebut.

Berdasarkan fenomena tersebut penelitian ini bermaksud untuk mengetahui hubungan antara kepercayaan diri dengan kemandirian belajar pada siswa XI IPS SMA Negeri 1 Porong.

\section{Metode}

Penelitian ini menggunakan metode penelitian kuantitatif dengan rancangan penelitian korelasional untuk mengungkap hubungan antara kepercayaan diri dengan kemandirian belajar pada siswa XI IPS SMA Negeri 1 Porong.

Populasi pada penelitian ini sebanyak 88 siswa yang merupakan siswa kelas XI IPS di SMA Negeri 1 Porong. Teknik pengambilan sampel pada penelitian ini adalah sampel sensus, karena sampel pada penelitian kurang dari 100. Sampel pada penelitian ini berjumlah sama dengan populasi yaitu 88 siswa.

Instrumen pada penelitian ini menggunakan skala kepercayaan diri dan kemandirian belajar. Skala kepercayaan diri disusun berdasarkan aspek-aspek kepercayaan diri yang dikemukakan oleh Lauster (dalam Ghufron, 2014). Skala kemandirian belajar disusun berdasarkan aspek-aspek kemandirian belajar yang 
dikemukakan oleh Abdullah (Rothwell, 2008)

Penelitian ini menggunakan teknik analisis data product moment, dikarenakan data penelitian berskala interval serta penelitian ini bertujuan untuk menguji hubungan satu variabel bebas dengan variabel terikat yaitu hubungan antara kepercayaan diri dengan kemandirian belajar. Analisis data dilakukan dengan menggunakan bantuan program SPSS versi 20.0 for windows.

\section{Hasil}

Penelitian ini bertujuan untuk mengetahui hubungan antara kepercayaan diri dengan kemandirian belajar. Hasil analisis data menggunakan korelasi product moment diperoleh nilai koefisien korelasi sebesar $(r)=0,683$ dan nilai signifikansi yang diperoleh variabel kepercayaan diri dan kemandirian belajar adalah $p=0,000(p<0,05)$. Hal ini berarti bahwa koefisien korelasi sebesar 0,683 menunjukkan kekuatan hubungan yang cukup antara variabel kepercayaan diri dengan kemandirian belajar dan nilai signifikansi yang didapat lebih kecil dari 0,05 sehingga kedua variabel tersebut memiliki hubungan yang signifikan. Berdasarkan hasil analisis tersebut, hipotesis penelitian yang menyatakan bahwa "ada hubungan antara kepercayaan diri dengan kemandirian belajar pada siswa XI IPS SMA Negeri 1 Porong" diterima.

\section{Pembahasan}

Hasil tersebut sejalan dengan pernyataan Heaters (dalam Nurhayati, 2011) kemandirian belajar seseorang dipengaruhi oleh kepercayaan diri. Seseorang yang memiliki kepercayaan diri akan yakin dengan kemampuannya dalam menyelesaikan berbagai macam permasalahan yang ada selama kegiatan belajar berlangsung, tanpa bantuan dari orang lain dan tidak ingin dikontrol pengambilan keputusannya untuk menyelesaikan permasalahan tersebut. Sama halnya dengan pernyataan Steinberg (dalam Desmita, 2011) kemandirian belajar siswa muncul ketika siswa menemukan diri pada posisi kepercayaan diri yang meningkat.

Menurut Brawer (dalam Darmawan, 2013) kemandirian belajar merupakan perasaan otonom dalam proses belajar dalam mengatur strategi, melaksanakan belajar, serta mengevaluasi hasil belajar. Sikap kemandirian umumnya dipengaruhi oleh self reliance atau kepercayaan diri yang dimiliki oleh individu. Seseorang yang mempunyai sikap mandiri harus dapat mengaktualisasikan secara optimal dan tidak menggantungkan diri kepada orang lain.

Chickering (Pannen, 2000) siswa yang mampu belajar mandiri adalah siswa yang dapat mengontrol dirinya sendiri, mempunyai motivasi yang tinggi, memiliki kepercayaan diri atau yakin akan dirinya, mempunyai orientasi atau wawasan yang luas dan luwes. Kepercayaan diri menjadi salah satu faktor penting dalam pencapaian kemandirian belajar pada siswa. Seorang siswa yang memiliki kepercayaan diri, akan yakin dengan berbagai keputusan yang diambil untuk mencapai prestasi belajar yang didapatkannya. Keyakinankeyakinan tersebut yang membuat siswa mampu mengambil berbagai langkah yang harus ditempuh dimulai dari perencanaan, pelaksanaan, serta evaluasi dari hasil yang telah didapatkannya.

Slameto (2003) keyakinan tentang diri kita sendiri dan penilaian tentang diri memiliki peran penting pada kemandirian peserta didik. Keyakinan tentang diri salah satu bentuk dari rasa percaya diri. Berhubungan dengan kemandirian belajar, rasa percaya diri memberikan pengertian bahwa sikap dan pandangan positif individu terhadap kemampuan dirinya akan meningkatkan kemandiriannya. 
Kepercayaan diri merupakan keyakinan akan kemampuannya dan sejauhmana penilaian individu terhadap dirinya bahwa dirinya memiliki kepantasan untuk berhasil (Neill, 2005). Kepercayaan diri siswa mempunyai peran yang sangat signifikan dalam kegiatan belajar. Jika siswa dalam belajar mempunyai kepercayaan diri yang tinggi maka hasil yang diperolehnya akan maksimal. Kepercayaan diri mempengaruhi kemandirian siswa dalam mengambil keputusan sendiri tanpa pengaruh dari orang lain, siswa yang mandiri mampu memotivasi diri untuk bertahan dari kesulitan yang dihadapi dan dapat menerima kegagalan dengan pikiran yang rasional. Seorang siswa yang memiliki kepercayaan diri dalam proses belajarnya dapat menerapkan sikap optimis serta bertanggungjawab dengan kewajiban yang dimilikinya sebagai siswa. Mereka selalu berpandangan positif, bahwa dirinya mampu menyelesaikan semua tugas belajar dengan baik dan mereka memiliki kesempatan untuk berhasil (Angelis, 2003).

Individu yang tidak memiliki kepercayaan diri, mereka cenderung berpandangan negatif, dan beranggapan apapun rintangan yang mereka lalui tidak ada terdapat jalan keluar. Mereka juga berpandangan bahwa kemampuan mereka terbatas dan tidak mungkin dapat mencapai keberhasilan. Individu yang memiliki kepercayaan diri rendah, cenderung bersikap pesimis dalam menjalani sesuatu. Mereka cenderung menyerah sebelum bertindak (Ghufron \& Risnawati 2014).

Berdasarkan penelitian Tahar dan Eceng (2006) menyatakan kemandirian belajar merupakan kesiapan dari individu yang mau dan mampu untuk belajar dengan inisiatif sendiri, dengan atau tanpa bantuan pihak lain dalam hal penentuan tujuan belajar, metode belajar, dan evaluasi hasil belajar. Unsur-unsur yang berperan dalam kemandirian belajar antara lain adanya rasa tanggung jawab, percaya diri, inisiatif dan motivasi sendiri dengan atau tanpa bantuan orang lain yang relevan untuk menguasai kompetensi tertentu, baik dalam aspek pengetahuan, keterampilan, maupun sikap yang dapat digunakan untuk memecahkan masalah belajar. Individu yang memiliki sikap positif terhadap dirinya mengenai kompetensi, keyakinan, serta ketrampilan yang dimilikinya mampu mengarahkan individu menjadi mandiri dalam mengelola proses belajarnya sendiri.

Menurut Jin dan Cortazzi (dalam Gyanprakash dkk, 2013) siswa yang memiliki keyakinan akan kemampuannya dan motivasi dalam proses belajarnya dapat memunculkan kemandirian belajar dalam diri siswa. Siswa tidak akan bergantung dengan orang lain dalam proses belajar dan memiliki dorongan untuk mencapai tujuan yang diinginkannya. Tiga komponen kemandirian belajar yaitu menentukan tujuan pembelajaran yang siap untuk belajar, terlibat dalam proses pembelajaran, dan mengevaluasi pembelajaran. Individu yang memiliki kemandirian belajar, akan yakin dengan kemampuannya untuk melaksanakan komponen kemandirian belajar mulai dari menentukan tujuan pembelajaran yang berisi rancangan dan harapan yang ingin dicapai, terlibat langsung dalam proses pembelajaran tanpa bergantung dengan orang lain, serta mampu mengevaluasi kemampuannya berdasarkan kemampuan yang dimilikinya.

Steinberg (dalam Desmita, 2011) menyebutkan bahwa kemandirian belajar dapat muncul dan berfungsi, apabila individu memiliki kepercayaan diri yang meningkat. Individu yang tidak memiliki tingkat kepercayaan diri yang tinggi, tidak dapat menumbuhkan sikap kemandirian belajar dalam dirinya. Oleh karena itu, siswa yang memiliki kepercayaan diri umumnya mampu memiliki keyakinan bahwa apapun langkah yang ditempuh dalam kegiatan belajarnya mampu memberikan hasil yang memuaskan nantinya. Siswa yang memiliki kepercayaan diri, akan mampu 
memberikan beberapa ide yang kreatif dalam proses pembelajarannya. Siswa yang mampu mengontrol dirinya dalam kegiatan belajarnya, mampu mengetahui kapan harus mengeluarkan berbagai inisiatif yang dimilikinya dan kapan harus bertanggung jawab dengan kewajibannya sebagai siswa (Miarso dalam Nurhayati, 2011).

Siswa yang memiliki kemandirian belajar, memiliki tanggung jawab dalam pengambilan keputusan yang berhubungan dengan usaha belajar. Mereka tidak akan mudah terpengaruh oleh orang lain mengenai proses belajarnya. Mereka akan berusaha semaksimal mungkin untuk menyelesaikan permasalahannya sendiri tanpa bantuan orang lain. Mereka juga mampu memanfaatkan waktu dengan sebaik mungkin untuk belajar. Individu yang memiliki kemandirian belajar tidak akan memilih bersenang-senang dibandingkan dengan belajar demi mencapai tujuannya.

Berdasarkan hal tersebut, maka dapat dijelaskan bahwa kemandirian belajar akan dapat dicapai ketika siswa memiliki kepercayaan diri. Kepercayaan diri memberikan kontribusi yang cukup penting dalam pembentukan kemandiran belajar dalam diri siswa. Hasil penelitian menunjukkan adanya korelasi yang cukup antara kepercayaan diri dengan kemandirian belajar. Kepercayaan diri memberikan kontribusi sebesar 68,3\% terhadap kemandirian belajar siswa, sedangkan $31,7 \%$ terdapat variabel lainnya seperti motivasi, tanggung jawab, inisiatif, dan lain sebagainya yang memberikan kontribusi terhadap kemandirian belajar siswa.

\section{Simpulan}

Berdasarkan penelitian yang berjudul "Hubungan Antara Kepercayaan Diri dengan Kemandirian belajar pada siswa XI IPS SMA Negeri 1 Porong" dapat ditarik kesimpulan bahwa hipotesis yang berbunyi "tidak ada hubungan antara kepercayaan diri dengan kemandirian belajar" ditolak. Kepercayaan diri memiliki hubungan dengan kemandirian belajar. Kedua variabel memiliki hubungan yang searah, artinya apabila siswa memiliki kepercayaan diri yang tinggi maka dapat meningkatkan kemandirian belajar sebaliknya apabila siswa memiliki kepercayaan diri rendah maka dapat menurunkan kemandirian belajar siswa.

\section{Daftar Pustaka}

Angelis, B. (2003). Percaya diri: sumber sukses dan kemandirian. Jakarta: PT. Gramedia Pustaka Utama.

Darmawan, M. (2013). Peningkatan kemandirian peserta didik melalui strategi pembelajaran problem solving pada kompetensi perawatan dan perbaikan PC di kelas X TKJ SMK Negeri 3 Yogyakarta. Jurnal EKSIS, 6 (2), 53-64. http://library.ukdw.ac.id/. Diakses 23 Desember 2015.
Desmita (2011). Psikologi perkembangan peserta didik. Bandung: PT. Remaja Rosdakarya

Hakim, T. (2002). Mengenal rasa tidak percaya diri. Jakarta: Puspa Swara.

Ghufron, M.N. \& Risnawita, R.S. (2014). Teori-teori psikologi. Yogyakarta: Ar-Ruzz Media

Gyanprakash., Nagpal, K., James, L. (2013). Independent learning and student development. International journal of social science \& interdisciplinary research, 2 (2), 17-35. 
http://indianresearchjournals.com.

Diakses 20 Desember 2015

Neill, J. (2005). Jenis-jenis percaya diri. Jakarta: Alfabeta

Nurhayati, E. (2011). Psikologi pendidikan inovatif. Yogyakarta: Pustaka Belajar

Pannen, P. (2001). Konstruktivisme dalam pembelajaran. Jakarta: Universitas Terbuka.

Rothwell, W.J. (2008). Adult learning basics. Virginia: ASTD Press

Santrock, J.W. (2003). Adolescence: perkembangan remaja (6th ed).
Shinto, B.A \& Sherly, S. (Terj). Jakarta: Erlangga

Slameto. (2003). Belajar dan Faktorfaktor yang Mempengaruhinya. Jakarta :Rineka Cipta.

Tahar, Irzan \& Enceng. 2006. Hubungan Kemandirian Belajar dan Hasil Belajar Pada Pendidikan Jarak Jauh. Jurnal Pendidikan Terbuka dan Jarak Jauh, 7 (2), 91-101. www.Ippm.ut.ac.id/. Diakses 23 Desember 2015.

Undang-undang Nomor 20 tahun 2003 tentang Sistem Pendidikan Nasional. 